\title{
EFFECT OF THERMAL TREATMENT ON THE CHEMICAL CHARACTERISTICS OF WOOD FROM Eucalyptus grandis W. Hill ex Maiden UNDER DIFFERENT ATMOSPHERIC CONDITIONS
}

\author{
Luiz Fernando de Moura ${ }^{1}$, José Otávio Brito², Francides Gomes da Silva Júnior ${ }^{3}$
}

(received: August 4, 2010; accepted: February 28, 2012)

\begin{abstract}
Thermal treatment (thermal rectification) is a process in which technological properties of wood are modified using thermal energy, the result of which is often value-added wood. Thermally treated wood takes on similar color shades to tropical woods and offers considerable resistance to destructive microorganisms and climate action, in addition to having high dimensional stability and low hygroscopicity. Wood samples of Eucalyptus grandis were subjected to various thermal treatments, as performed in presence $\left(140^{\circ} \mathrm{C} ; 160^{\circ} \mathrm{C} ; 180^{\circ} \mathrm{C}\right)$ or in absence of oxygen $\left(160^{\circ} \mathrm{C} ; 180^{\circ} \mathrm{C} ; 200^{\circ} \mathrm{C}\right)$ inside a thermal treatment chamber, and then studied as to their chemical characteristics. Increasing the maximum treatment temperatures led to a reduction in the holocellulose content of samples as a result of the degradation and volatilization of hemicelluloses, also leading to an increase in the relative lignin content. Except for glucose, all monosaccharide levels were found to decrease in samples after the thermal treatment at a maximum temperature of $200^{\circ} \mathrm{C}$. The thermal treatment above $160^{\circ} \mathrm{C}$ led to increased levels of total extractives in the wood samples, probably ascribed to the emergence of low molecular weight substances as a result of thermal degradation. Overall, it was not possible to clearly determine the effect of presence or absence of oxygen in the air during thermal treatment on the chemical characteristics of the relevant wood samples.
\end{abstract}

Key words: Heat treatment, wood chemistry, eucalyptus.

\section{EFEITO DA TERMORRETIFICAÇÃO NAS CARACTERÍSTICAS QUÍMICAS DA MADEIRA DE Eucalyptus grandis W. Hill ex Maiden TRATADA SOB DIFERENTES CONDIÇÕES DE ATMOSFERA}

\begin{abstract}
RESUMO: A termorretificação (ou retificação térmica) é um processo de alteração das propriedades tecnológicas da madeira, utilizando-se energia térmica, cujos resultados obtidos, normalmente, resultam na agregação de valor à madeira. A madeira termorretificada adquire colorações semelhantes àquelas de madeiras tropicais, considerável resistência aos microorganismos xilófagos e à ação climática, alta estabilidade dimensional e baixa higroscopicidade. Amostras de Eucalyptus grandis foram submetidas a diversos tratamentos de termorretificação, executados em presença $\left(140^{\circ} \mathrm{C} ; 160^{\circ} \mathrm{C} ; 180^{\circ} \mathrm{C}\right)$ ou escassez de oxigênio $\left(160^{\circ} \mathrm{C} ; 180^{\circ} \mathrm{C} ; 200^{\circ} \mathrm{C}\right)$ na atmosfera do interior da câmara de tratamento térmico, e estudadas quanto às suas características químicas. O aumento das temperaturas máximas de tratamento causou redução no teor de holocelulose das amostras, em razão da degradação e volatilização de hemiceluloses, além de proporcionar um incremento no teor relativo de lignina. Todos os monossacarídeos, com exceção da glicose, tiveram sua proporção reduzida na madeira após o tratamento térmico à temperatura máxima de $200^{\circ} \mathrm{C}$. A termorretificação acima de $160^{\circ} \mathrm{C}$ levou a um incremento no teor de extrativos totais da madeira, provavelmente atribuído ao surgimento de substâncias de peso molecular reduzido, em razão da degradação térmica. De maneira geral, não foi possivel determinar com clareza o efeito das condições de presença ou escassez de oxigênio do ar durante a termorretificação sobre as características químicas da madeira tratada.
\end{abstract}

Palavras-chave: Tratamento térmico, química da madeira, eucalipto.

\section{INTRODUCTION}

Tropical wood species have high economic value in the international market on account of their excellent structural and decorative characteristics, yet the worldwide reserves of tropical wood species are currently in decline. A possible solution to this problem is use of alternative, rapidly growing species of lower economic value originated in reforested areas (native or exotic). Overall, these species have inferior physicomechanical properties and are less resistant to attack by microorganisms.

\footnotetext{
'Forest Engineer, Professor PhD in Wood Machining - Universidade de São Paulo/USP - Escola Superior de Agricultura "Luiz de Queiroz"/ESALQ Departamento de Ciências Florestais - Av. Pádua Dias, no 11 - Cx. P. 09 - 13.418-900 - Piracicaba, SP, Brasil - demoura.LF@gmail.com ${ }^{2}$ Forest Engineer, Professor PhD in Soils and Plant Nutrition - Universidade de São Paulo/USP-Escola Superior de Agricultura "Luiz de Queiroz"/ESALQDepartamento de Ciências Florestais - Av. Pádua Dias, no 11 - Cx. P. 09 - 13.418-900 - Piracicaba, SP, Brasil - jobrito@usp.br ${ }^{3}$ Forest Engineer, Professor PhD in Chemical Engineering - Universidade de São Paulo/USP - Escola Superior de Agricultura “Luiz de Queiroz"/ESALQDepartamento de Ciências Florestais - Av. Pádua Dias, no 11 - Cx. P. 09 - 13.418-900 - Piracicaba, SP, Brasil - fgomes@esalq.usp.br
}

Cerne, Lavras, v. 18, n. 3, p. 449-455, jul./set. 2012 
The most commonly used technique to improve resistance to attack by microorganisms is impregnating wood with heavy metals (chromium, copper and arsenic or bromine) or using creosote. However, these preserving products are highly hazardous to the environment as they contaminate both groundwater and the soil, in addition to restricting wood use to more selective applications, such as furniture making. On account of their toxicity, these products have been forbidden in North American and European countries.

Thermal treatment is a possible alternative for improving physical characteristics, increasing durability and enhancing the appearance of wood. Thermally treated wood takes on similar color shades to tropical woods and offers considerable resistance to destructive microorganisms and climate action, in addition to having high dimensional stability and low hygroscopicity. The material is therefore recommended for use in moist indoor and outdoor environments not involving considerable mechanical stresses.

In Brazil, wood is relatively little used for the external finish of houses. At the same time, wood furniture intended for use in outdoor environments is increasingly losing ground to products made from plastic and aluminum. Therefore, a market shortage is noted of competitive wood-based materials intended for use in outdoor environments. Thermally treated wood, with all of its attached comparative advantages against wood in natural form, could meet a share of this market demand. With this in mind, special emphasis is placed on the importance of understanding the effects of thermal treatment as a tool to improve wood properties and characteristics.

The enhanced dimensional stability of thermally treated wood is associated to the decrease in its hygroscopicity. During the heating process, a portion of the hydrophilic polysaccharides (hemicelluloses) existing in wood vaporizes, reducing hydroxyl radicals where water molecules would normally attach. There is also a relative increase in lignin proportion, increasing the hydrophobic nature of the material. Therefore, species with a higher initial level of hemicelluloses tend to become more hydrophobic after thermal treatment. The hydrophobic nature of treated wood and the densification of the lignin network are strong allies in boosting wood resistance to cellulose- and lignin-destroying fungi (DUCHEZ; GUYONNET, 1998).

Cerne, Lavras, v. 18, n. 3, p. 449-455, jul./set. 2012
After subjecting isolated chemical components of wood from Eucalyptus spp. to a constant temperature of $300^{\circ} \mathrm{C}$, Brito and Barrichelo (1979) reported that holocellulose degrades at a rate twice as high as lignin. Based on that claim, it can be inferred that the maximum temperature of thermal treatment applied in this study $\left(200^{\circ} \mathrm{C}\right)$ will not suffice to degrade lignin, though it may cause an initial reduction in the level of hydrophilic components of holocellulose.

While studying the effects of a thermal treatment program on the chemical characteristics of wood from Eucalyptus saligna, Brito et al. (2008) reported the following changes as a function of a temperature increase reaching up to $180^{\circ} \mathrm{C}$ : a reduction in arabinose, mannose, galactose and xylose levels (constituent parts of hemicelluloses); a maintenance of the glucose content; an increase in relative levels of lignin and extractives.

In this work, samples of Eucalyptus grandis were subjected to various thermal treatment programs reaching up to $200^{\circ} \mathrm{C}$, in presence or absence of oxygen in the air, and were then analyzed as to their chemical characteristics.

\section{MATERIAL AND METHODS}

\subsection{Material}

The variety selected was Eucalyptus grandis W. Hill ex Maiden, as this species has great potential for meeting the domestic demand from the timber industry. Trees were collected from stands at age 18 years, located in Anhembi-SP experimental station of the department of forest sciences of ESALQ/USP. This study being part of a research program focused on use of eucalyptus wood for the manufacture of furniture intended for outdoor environments, tree sampling was based on diameter standards consistent with furniture making purposes.

Logs $300 \mathrm{~cm}$ in length were removed $40 \mathrm{~cm}$ above ground level, and then tangential boards $280 \times 8 \times 5 \mathrm{~cm}$ were cut in the radial direction from the intermediate portion of the stem, as illustrated in Figure 1. The boards were then cut into four subsamples $60 \times 8 \times 5 \mathrm{~cm}$ each, eliminating any defective parts (cracks, knots, warps etc.). For each of the boards, one of the subsamples was used in natural form as a control sample while the other three were subjected to thermal treatments. The pieces selected for thermal treatments ( 7 samples per treatment) were dried in a forced-air oven set at $100^{\circ} \mathrm{C}$ to a constant weight (PINCELLI et al., 2002). 


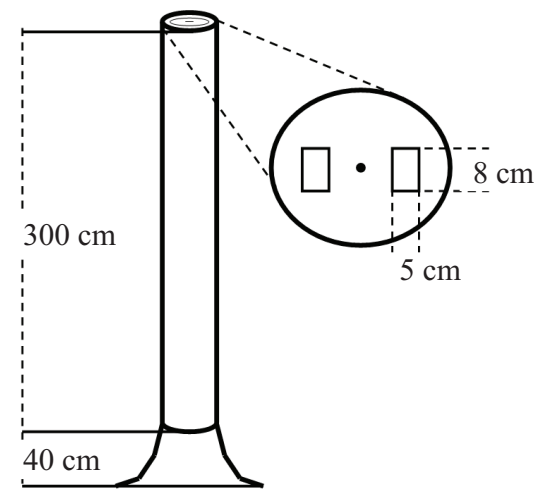

Figure 1 - Illustration of sample position relative to the tree stem.

Figura 1 - Esquema ilustrando a posição das amostras em relação ao fuste das árvores.

\subsection{Thermal treatments}

The thermal treatments were conducted in the integrated laboratories of chemistry, pulp and energy (LQCE) of the department of forest sciences of ESALQ/ USP. Wood samples were thermally treated in a FANEM Model 320 incubator equipped with an electric resistance heating and forced-air circulation system, with a nominal volume of 450 liters. The samples were initially placed inside closed metal boxes (Figure 2) equipped with an access and openings for the placing of wiring for a temperature control system, an access for extraction of process gases and introduction of inert gases into the internal atmosphere, as required (Figure $2 \mathrm{a}$ and $2 \mathrm{~b}$ ). Boxes containing the wood samples were placed in the incubator with a preset temperature of $100^{\circ} \mathrm{C}$ and the thermal treatment was then initiated according to programs illustrated in Figure 3.

In order to test the effect of oxygen absence in the thermal treatment chamber, injection of industrial gaseous nitrogen ( $99.5 \%$ purity) into the chamber was also performed for treatments with temperatures above $160^{\circ} \mathrm{C}$. This measure was aimed at reducing the oxygen level inside the thermal treatment chamber to levels below $1 \%$.

\subsection{Chemical analyses}

Analyses included determination of Klason lignin and total extractives soluble in ethanol:toluene, at a 2:1 ratio, and in hot water. The holocellulose content (cellulose and hemicelluloses) was calculated by subtracting the sum of lignin and extractives from the total dry weight being analyzed $(\% \mathrm{H}=1-(\% \mathrm{ET}+\% \mathrm{~L}))$. All samples were subjected to these chemical analyses.

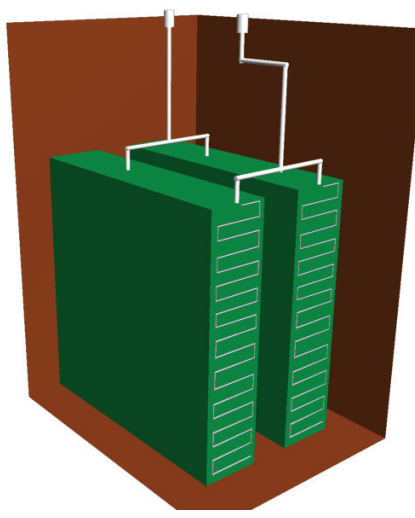

(a)

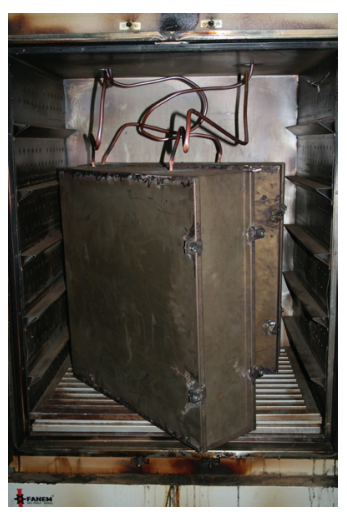

(b)
Figure 2 - Project of boxes for installation inside the incubator, for injection of gaseous nitrogen: a) Right pipe for gas inlet, left pipe for gas outlet; b) Broad view of the installed system.

Figura 2 - Projeto das caixas para instalação no interior da estufa, visando à injeção de nitrogênio gasoso: a) Tubulação à direita para entrada do gás, tubulação à esquerda para a saída do gás; b) Visão geral do sistema instalado na estufa.

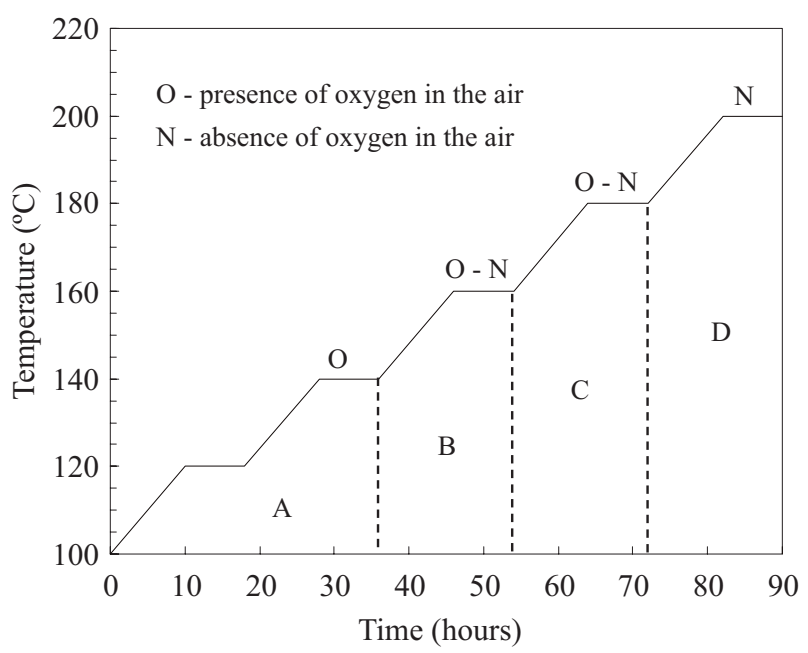

Figure 3 - Programs used for thermal treatments at maximum temperatures of $140^{\circ} \mathrm{C}, 160^{\circ} \mathrm{C}, 180^{\circ} \mathrm{C}$ and $200^{\circ} \mathrm{C}$.

Figura 3 - Programas usados para termorretificações às temperaturas máximas de $140^{\circ} \mathrm{C}, 160^{\circ} \mathrm{C}, 180^{\circ} \mathrm{C}$ e $200^{\circ} \mathrm{C}$.

Carbohydrate levels were quantified in samples thermally treated at a maximum temperature of $200^{\circ} \mathrm{C}$, and in untreated control samples. Air-dried samples were subjected to primary hydrolysis in conformity with TAPPI method $249 \mathrm{~cm}-85$ (TAPPI, 1993). A second hydrolysis was carried out by diluting the sample in an autoclave.

Cerne, Lavras, v. 18, n. 3, p. 449-455, jul./set. 2012 
The analysis of carbohydrates was performed using a DIONEX DX500 liquid ion chromatography system, equipped with a CarboPAC PA 1 column and pulsed amperometric detection, applying a 4-potential waveform.

\subsection{Analysis of results}

Results were statistically assessed using analysis of variance (ANOVA) and multiple means comparison tests (Tukey Test). The means comparison tests referring to treatment type (i.e. in presence or absence of oxygen) were performed only for maximum temperatures of $160^{\circ} \mathrm{C}$ and $180^{\circ} \mathrm{C}$.

\section{RESULTS AND DISCUSSION}

\subsection{Total extractives content}

Analysis results regarding total extractives content $(\% \mathrm{ET})$ found in wood from Eucalyptus grandis thermally treated at three maximum temperatures in presence or absence of oxygen, and the relevant untreated control samples, are illustrated in Table 1, along with multiple statistical mean comparisons, for all parameters being studied.

Table 1 - Multiple statistical comparisons for total extractives content (\%ET) found in wood from Eucalyptus grandis subjected to various thermal treatment conditions.

Tabela 1 - Comparações estatísticas múltiplas do teor de extrativos totais (\%ET), determinado na madeira de Eucalyptus grandis, submetida a diversas condições de termorretificação.

\begin{tabular}{lccccc}
\hline Atmosphere & $\begin{array}{c}\text { Maximum } \\
\text { temperature } \\
\left({ }^{\circ} \mathrm{C}\right)\end{array}$ & \% ET & $\begin{array}{c}\text { Standard } \\
\text { error }\end{array}$ & $\mathrm{C} 1$ & $\mathrm{C} 2$ \\
& Control & 7.85 & 0.02 & $\underline{\mathrm{B}}$ & \\
Presence of oxygen & 140 & 6.66 & 0.36 & $\underline{\mathrm{BC}}$ & \\
& 160 & 6.39 & 0.26 & $\underline{\mathrm{C}}$ & $\mathrm{b}$ \\
& 180 & 9.96 & 0.46 & $\underline{\mathrm{A}}$ & $\mathrm{a}$ \\
\hline & Control & 7.85 & 0.02 & $\underline{\mathrm{B}}$ & \\
Absence of oxygen & 160 & 7.81 & 0.16 & $\underline{\mathrm{B}}$ & $\mathrm{a}$ \\
& 180 & 11.40 & 0.31 & $\underline{\mathrm{A}}$ & $\mathrm{a}$ \\
& 200 & 10.93 & 0.30 & $\underline{\mathrm{A}}$ & \\
\hline
\end{tabular}

C1: UNDERLINED CAPITAL LETTERS refer to comparisons (Tukey Test) between maximum temperatures, for one type of treatment (presence or absence of oxygen).

C2: small letters refer to comparisons (Tukey Test) between types of treatment (presence or absence of oxygen), for a single maximum temperature. These comparisons were performed only for maximum temperatures of $160^{\circ} \mathrm{C}$ and $180^{\circ} \mathrm{C}$.

Cerne, Lavras, v. 18, n. 3, p. 449-455, jul./set. 2012
The wood from Eucalyptus grandis had a mean extractives content of $8.65 \%$. The extractives content was reduced in samples treated up to $160^{\circ} \mathrm{C}$, noticeably in the treatment with oxygen presence in the air. Thermal treatment above $160^{\circ} \mathrm{C}$, however, caused an abrupt increase in the total extractives content (Table 1, C1). A similar increase in extractives level was also reported by Brito et al. (2008) for Eucalyptus saligna when treated at temperatures above $160^{\circ} \mathrm{C}$.

The reduction in \%ET occurs, with heating up to a certain point $\left(160^{\circ} \mathrm{C}\right)$, due to the isolated effect of degradation and volatilization of extractives originally present in the wood. The degradation of extractives is related to oxidation reactions, accelerated by the effect of rising temperatures.

However, as a result of the initial stage of thermal degradation of other wood components above $160^{\circ} \mathrm{C}$, low molecular weight substances are assumed to emerge supposedly extracted during the chemical analyses. It is thus assumed that a share of the substances extracted from samples treated above $160^{\circ} \mathrm{C}$ is not constituted by the original extractives of the wood in natural form, which is an indication of the onset of thermal degradation.

The overall mean of extractives content was lower in presence $(8.18 \%)$ than in absence of oxygen $(9.61 \%$, means at $160^{\circ} \mathrm{C}$ and $180^{\circ} \mathrm{C}$ ). For the thermal treatment in presence of oxygen, the wood showed a more severe reduction in $\% \mathrm{ET}$ up to $160^{\circ} \mathrm{C}(18.6 \%)$ than was observed in the treatment in absence of oxygen $(0.51 \%)$, resulting in a lower extractives content (Table 1, C2). Results thus suggest that the absence of oxygen in the air to some extent undermined the degradation and volatilization of extractives in the wood through temperature, probably because of the conditions less favorable to oxidation reactions.

\subsection{Lignin content}

Analysis results of lignin content found in wood from Eucalyptus grandis thermally treated at three maximum temperatures in presence or in absence of oxygen, and relevant untreated control samples, are illustrated in Table 2, along with multiple statistical mean comparisons, for all parameters being studied.

The mean lignin content found in wood from Eucalyptus grandis was $33.87 \%$. The lignin proportion increased as a function of increasing maximum temperature in the thermal treatment (Table 2, $\mathrm{C} 1 ; \mathrm{r}=0.3996$ ), confirming findings obtained by Brito et al. (2008), Kamdem et al. (2002) and Sivonen et al. (2002). This result 
Table 2 - Multiple statistical comparisons for lignin content $(\% \mathrm{~L})$ found in wood from Eucalyptus grandis subjected to various thermal treatment conditions.

Tabela 2 - Comparações estatísticas múltiplas do teor de lignina $(\%$ L), determinado na madeira de Eucalyptus grandis, submetida a diversas condições de termorretificação.

\begin{tabular}{lccccc}
\hline Atmosphere & $\begin{array}{c}\text { Maximum } \\
\text { temperature } \\
\left({ }^{\circ} \mathrm{C}\right)\end{array}$ & $\% \mathrm{~L}$ & $\begin{array}{c}\text { Standard } \\
\text { error }\end{array}$ & $\mathrm{C} 1$ & $\mathrm{C} 2$ \\
& Control & 31.92 & 0.25 & $\underline{\mathrm{B}}$ & \\
\hline Presence of oxygen & 140 & 31.43 & 0.38 & $\underline{\mathrm{B}}$ & \\
& 160 & 32.17 & 0.06 & $\underline{\mathrm{B}}$ & $\mathrm{a}$ \\
& 180 & 35.18 & 0.31 & $\underline{\mathrm{A}}$ & $\mathrm{a}$ \\
\hline & Control & 31.92 & 0.25 & $\underline{\mathrm{C}}$ & \\
Absence of oxygen & 160 & 33.25 & 0.08 & $\underline{\mathrm{B}}$ & $\mathrm{a}$ \\
& 180 & 33.77 & 0.49 & $\underline{\mathrm{B}}$ & $\mathrm{a}$ \\
& 200 & 38.83 & 0.18 & $\underline{\mathrm{A}}$ & \\
\hline
\end{tabular}

C1: UNDERLINED CAPITAL LETTERS refer to comparisons (Tukey Test) between maximum temperatures, for one type of treatment (presence or absence of oxygen).

C2: small letters refer to comparisons (Tukey Test) between types of treatment (presence or absence of oxygen), for one maximum temperature. These comparisons were performed only for maximum temperatures of $160^{\circ} \mathrm{C}$ and $180^{\circ} \mathrm{C}$.

was expected, given that, among all chemical components of wood, lignin is the most resistant to thermal degradation (BRITO; BARRICHELO, 1979). Accordingly, while other components may have started to degrade and/or volatilize during thermal treatment at maximum temperatures above $180^{\circ} \mathrm{C}$ (hemicelluloses and extractives), lignin went through no apparent thermal degradation, its quantity remaining intact. The relative lignin content was positively correlated with maximum temperature $(r=0.6197)$.

Lignin content means were similar for thermally treated samples in presence (33.68\%) and in absence of oxygen (33.51\%) (Table 2, C2). Therefore, the oxygen levels in the atmosphere of the thermal treatment did not exert any noticeable effect on the relative lignin content.

\subsection{Holocellulose content}

Holocellulose contents (cellulose and hemicelluloses) in wood from Eucalyptus grandis thermally treated at three maximum temperatures in presence or in absence of oxygen, and relevant untreated control samples, are illustrated in Table 3, along with multiple statistical mean comparisons, for all parameters being studied.
Table 3 - Multiple statistical comparisons for holocellulose content $(\% \mathrm{H})$ found in wood from Eucalyptus grandis subjected to various thermal treatment conditions.

Tabela 3 - Comparações estatísticas múltiplas do teor de holocelulose $(\% H)$, determinado na madeira de Eucalyptus grandis, submetida a diversas condições de termorretificação.

\begin{tabular}{lccccc}
\hline Atmosphere & $\begin{array}{c}\text { Maximum } \\
\text { temperature } \\
\left({ }^{\circ} \mathrm{C}\right)\end{array}$ & $\% \mathrm{H}$ & $\begin{array}{c}\text { Standard } \\
\text { error }\end{array}$ & $\mathrm{C} 1$ & $\mathrm{C} 2$ \\
& Control & 60.22 & 0.27 & $\underline{\mathrm{A}}$ & \\
\hline \multirow{3}{*}{ Presence of oxygen } & 140 & 61.90 & 0.69 & $\underline{\mathrm{A}}$ & \\
& 160 & 61.44 & 0.27 & $\underline{\mathrm{A}}$ & $\mathrm{a}$ \\
& 180 & 54.86 & 0.69 & $\underline{\mathrm{B}}$ & $\mathrm{a}$ \\
\hline & Control & 60.22 & 0.27 & $\underline{\mathrm{A}}$ & \\
Absence of oxygen & 160 & 58.95 & 0.09 & $\underline{\mathrm{B}}$ & $\mathrm{b}$ \\
& 180 & 54.84 & 0.20 & $\underline{\mathrm{C}}$ & $\mathrm{a}$ \\
& 200 & 50.23 & 0.35 & $\underline{\mathrm{D}}$ & \\
\hline
\end{tabular}

C1: UNDERLINED CAPITAL LETTERS refer to comparisons (Tukey Test) between maximum temperatures, for one type of treatment (presence or absence of oxygen).

C2: small letters refer to comparisons (Tukey Test) between types of treatment (presence or absence of oxygen), for one maximum temperature. These comparisons were performed only for maximum temperatures of $160^{\circ} \mathrm{C}$ and $180^{\circ} \mathrm{C}$.

The overall mean holocellulose content in Eucalyptus grandis was $57.48 \%$. Maximum temperatures applied during thermal treatment sufficed to cause initial degradation of hemicelluloses. There was a significant reduction in holocellulose content as a function of increase in maximum temperature (Table $3, \mathrm{C} 1 ; \mathrm{r}=-0.5910$ ), this reduction being more pronounced in treatments above $160^{\circ} \mathrm{C}$.

For treatments in presence of oxygen, the holocellulose content remained unchanged up to $160^{\circ} \mathrm{C}$, followed by a $10.7 \%$ decrease in the interval up to a maximum temperature of $180^{\circ} \mathrm{C}$. Where the atmosphere was poor in oxygen, the holocellulose content decreased only by $2.1 \%$ up to $160^{\circ} \mathrm{C}$, in comparison with control samples, whereas in the $160^{\circ} \mathrm{C}$ to $180^{\circ} \mathrm{C}$ interval there was a $7.0 \%$ reduction (Table $3, \mathrm{C} 1$ ).

Where samples were thermally treated in presence of oxygen in the air, the holocellulose content $(58.15 \%)$ was slightly higher than in absence of oxygen $(56.90 \%$, means at $160^{\circ} \mathrm{C}$ and $180^{\circ} \mathrm{C}$ ). Yet this superiority was only attributed to the temperature of $160^{\circ} \mathrm{C}$ (Table 3 , C2).

Cerne, Lavras, v. 18, n. 3, p. 449-455, jul./set. 2012 


\subsection{Carbohydrate contents}

Carbohydrate contents found for Eucalyptus grandis thermally treated at a maximum temperature of $200^{\circ} \mathrm{C}$, and relevant untreated control samples, are illustrated in Figure 4.
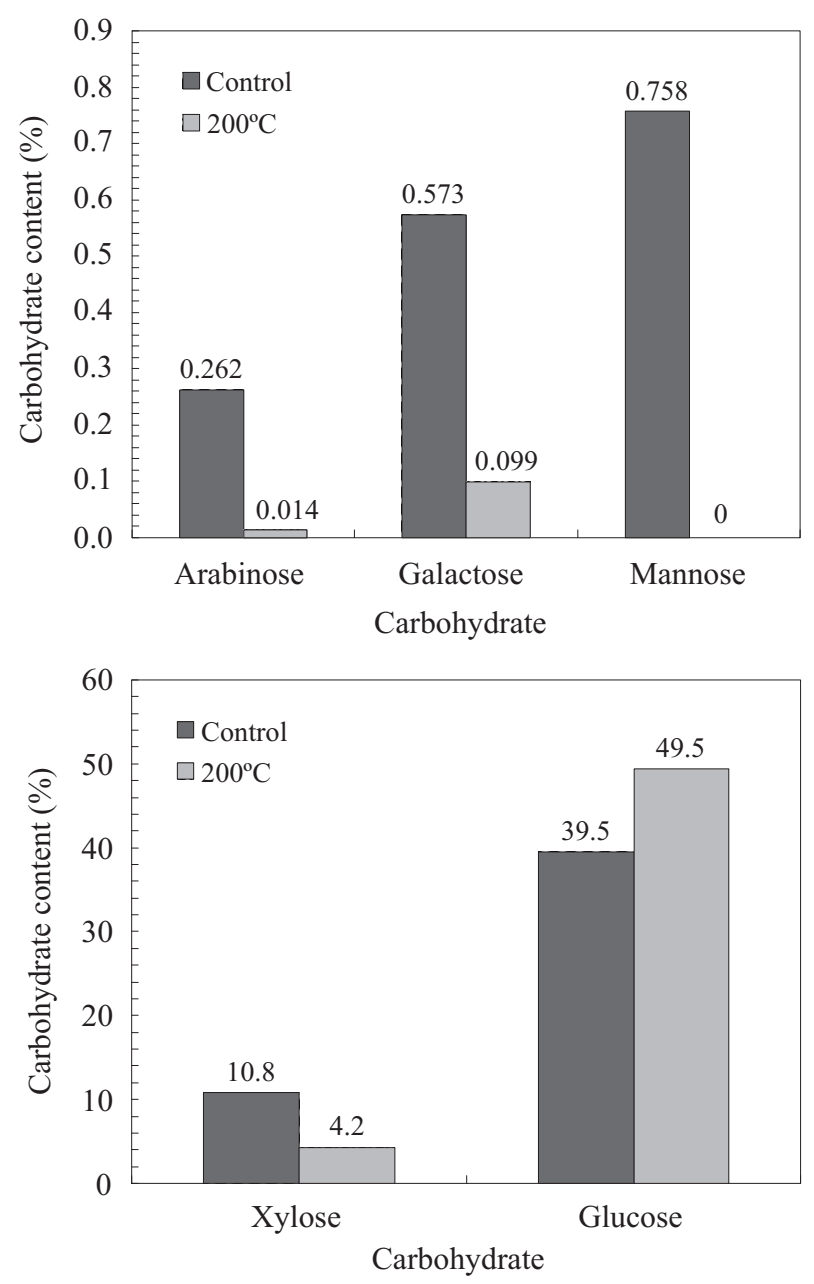

Figure 4 - Carbohydrate contents in wood from Eucalyptus grandis before and after thermal treatment at a maximum temperature of $200^{\circ} \mathrm{C}$.

Figura 4 - Teor de carboidratos na madeira de Eucalyptus grandis antes e após termorretificação à temperatura máxima de $200^{\circ} \mathrm{C}$.

Overall, xylose (pentose) was the second most frequent carbohydrate found in the wood of Eucalyptus grandis, followed by mannose (hexose) which was only present in a minute amount (Figure 4). Smaller amounts were found of carbohydrates galactose (hexose) and arabinose (pentose).

All monosaccharides, except glucose, were significantly reduced in the wood samples after thermal treatment at a maximum temperature of $200^{\circ} \mathrm{C}$, due to resulting degradation and volatilization. This pattern confirms findings reported by Brito et al. (2008).

The treatment at $200^{\circ} \mathrm{C}$ led to a complete degradation and volatilization of mannoses. The thermally treated samples showed drastic reduction of galactose and arabinose levels, almost completely eliminated by the action of temperature. It can be thus said that, after thermal treatment, the carbohydrate portion of the wood became almost exclusively composed of glucose and xylose (Figure 4).

As for the holocellulose component, the cellulose portion is the most resistant part to thermal degradation. There is no evidence in literature of the possibility of cellulose degrading and volatilizing in the range of maximum temperatures being tested (up to $200^{\circ} \mathrm{C}$ ). Hemicelluloses, on the other hand, the constituent parts of which were fully or partially eliminated with thermal treatment (Figure 4), already show volatilization and degradation in the range of temperatures being used (BRITO et al., 2008; CANAS et al., 2007; SIVONEN et al., 2002). Given that cellulose, which remains virtually intact at temperatures below $200^{\circ} \mathrm{C}$, is composed of glucose, it is expected that the amount of this monosaccharide also remain intact in the thermally treated samples, which leads to a relative increase in the proportion of this carbohydrate in samples. Thermal treatment led to an increase in the proportion of the above monosaccharide relative to sample weight. This pattern is an indication that cellulose underwent little or no degradation during the heating process.

\section{CONCLUSIONS}

The action of temperature led to changes in the proportion of chemical components in the thermally treated wood from Eucalyptus grandis. These changes were mainly attributed to degradation and volatilization of carbohydrates (pentoses and hexoses) that compose hemicelluloses. The holocellulose content decreased and the relative lignin content increased with the rise in maximum temperature during thermal treatment. After thermal treatment at $200^{\circ} \mathrm{C}$, the carbohydrate portion of the wood sample from $E$. grandis became almost exclusively composed of glucose and xylose.

Cerne, Lavras, v. 18, n. 3, p. 449-455, jul./set. 2012 
Thermal treatment above $160^{\circ} \mathrm{C}$ led to an increase in the total extractives content, probably due to the emergence of low molecular weight substances. It is thus assumed that a share of the substances extracted from the samples treated above $160^{\circ} \mathrm{C}$ is not constituted by the original extractives of wood in natural form, which is an indication of the onset of thermal degradation.

Overall, it was not possible to clearly determine the effect of presence or absence of oxygen in the air during thermal treatment on the chemical characteristics of the relevant wood samples. Yet, eliminating oxygen from the thermal treatment chamber is strongly recommended as a way of reducing fire risks, whenever temperatures used are above $180^{\circ} \mathrm{C}$.

\section{ACKNOWLEDGEMENTS}

This work was technically supported by A W Faber Castell S.A. and SENAI (Brazilian National Service of Industrial Learning "Mario Henrique Simonsen"), and relied on the contribution of Adriana Maria Nolasco (technical assistance), Giana Benati Falcin, in memorian (extractives and lignin determination), José Francisco Bis (sample machining), Lívia Paula Silva Palmeiras, Oscar Bahia Filho and Udemilson Luís Ceribelli (carbohydrates determination). The work was sponsored by FAPESP (São Paulo Research Aid Foundation).

\section{REFERENCES}

BRITO, J. O.; BARRICHELO, L. E. G. Comportamentos isolados da lignina e da celulose da madeira frente à carbonização. Piracicaba: IPEF, 1979. 4 p. (Circular Técnica IPEF, 28).
BRITO, J. O.; SILVA, F. G.; LEÃO, M. M.; ALMEIDA, G. Chemical composition changes in eucalyptus and pinus woods submitted to heat treatment. Bioresource Technology, Essex, v. 99, p. 8545-8548, 2008.

CANAS, S.; BELCHIOR, A. P.; FALCÃO, A.; GONÇALVES, J. A.; SPRANGER, M. I.; BRUNO-DE-SOUSA, R. Efeito do tratamento térmico nas modificações térmicas e químicas das madeiras de carvalho e de castanheiro utilizadas no envelhecimento de aguardentes. Ciência Técnica Vitivinícola, Colombo, v. 22, n. 1, p. 5-14, 2007.

DUCHEZ, L.; GUYONNET, R. Principles and applications of wood rectification. In: WORLD CONFERENCE ON TIMBER ENGINEERING, 5., 1998, Lausanne. Proceedings... Lausanne, 1998. 1 CD-ROM.

KAMDEM, D. P.; PIZZI, A.; JERMANNAUD, A. Durability of heat-treated wood. European Journal of Wood and Wood Products, Dordrecht, v. 60, n. 1, p. 1-6, Feb. 2002.

PINCELLI, A. L. P. S. M.; BRITO, J. O.; CORRENTE, J. E. Avaliação da termorretificação sobre a colagem na madeira de Eucalyptus saligna e Pinus caribaea var. hondurensis.

Scientia Forestalis, Piracicaba, v. 61, p. 122-132, jun. 2002.

SIVONEN, H.; MAUNU, S. L.; SUNDHOLM, F.; JÄMSÄ, S.; VIITANIEMI, P. Magnetic resonance studies of thermally modified wood. Holzforschung, Berlin, v. 56, n. 6, p. 648-654, Nov. 2002.

TAPPI. Tappi test methods: T-249 $\mathrm{cm}-85$ : carbohydrate composition of extractive free wood and wood pulp by gasliquid chromatography. Oxford, 1993.

Cerne, Lavras, v. 18, n. 3, p. 449-455, jul./set. 2012 
